\title{
Improving Nitrogen Use Efficiency in Cereal Grain Production with Optical Sensing and Variable Rate Application
}

\author{
William R. Raun,* John B. Solie, Gordon V. Johnson, Marvin L. Stone, Robert W. Mullen, Kyle W. Freeman,
} Wade E. Thomason, and Erna V. Lukina

\begin{abstract}
In 2001, $\mathbf{N}$ fertilizer prices nearly doubled as a result of increased natural gas prices. This was further troubling when considering that the world $\mathrm{N}$ use efficiency (NUE) in cereal grain production averages only $33 \%$. Methods to improve NUE in winter wheat (Triticum aestivum L.) have not included high spatial-resolution management based on sensed plant growth properties nor on midseason prediction of grain yield. Our objective was to determine the validity of using inseason estimates of grain yield (INSEY) and a response index (RI) to modulate $\mathrm{N}$ at $1-\mathrm{m}^{2}$ spatial resolution. Four winter wheat field experiments were conducted that evaluated prescribed midseason $\mathbf{N}$ applications compared with uniform rates that simulated farmer practices. Our methods recognize that each $1-\mathrm{m}^{2}$ area in wheat fields needs to be sensed and managed independently and that the need for fertilizer $\mathbf{N}$ is temporally dependent. Averaged over locations, NUE was improved by $>15 \%$ when $N$ fertilization was based on optically sensed INSEY, determined for each $1-\mathrm{m}^{2}$ area, and a RI compared with traditional practices at uniform $\mathrm{N}$ rates.
\end{abstract}

$\mathrm{W}$ ORLD CONSUMPTION of fertilizer N was 85529551 $\mathrm{Mg}$ in 1999 (FAO, 2001). Of the total fertilizer $\mathrm{N}$ consumed, cereal production accounts for $60 \%$, or $51317730 \mathrm{Mg}$ (FAO, 1995). Only 33\% of the total N applied for cereal production in the world is actually removed in the grain (Raun and Johnson, 1999), much less than that generally reported (Hardy and Havelka, 1975). In 1999, the unaccounted $67 \%$ represented a $\$ 15.9$ billion annual loss of $\mathrm{N}$ fertilizer (Raun and Johnson, 1999). With the increasing costs of $\mathrm{N}$ fertilizer due to natural gas shortages, the unaccounted $67 \%$ is now estimated to be worth more than $\$ 20$ billion annually. Considering these poor use efficiencies and the associated costs of improper management, technological advances are needed to reduce excess nutrient applications.

\section{Low Nitrogen Use Efficiency}

Nitrogen use efficiency (NUE) in cereal grain production is low for a variety of reasons. Plant $\mathrm{N}$ losses as $\mathrm{NH}_{3}$ have accounted for 52 to $73 \%$ of labeled $\mathrm{N}\left({ }^{15} \mathrm{~N}\right)$ in corn (Zea mays L.) (Francis et al., 1993) and $>21 \%$ in winter wheat (Harper et al., 1987; Daigger et al., 1976). Fertilizer $\mathrm{N}$ losses via denitrification have been estimated at $9.5 \%$ in winter wheat (Aulakh et al., 1982), $10 \%$ in rice (Oryza sativa L.) (DeDatta et al., 1991),

W.R. Raun, G.V. Johnson, R.W. Mullen, K.W. Freeman, W.E. Thomason, and E.V. Lukina, Dep. of Plant and Soil Sci., and J.B. Solie and M.L. Stone, Dep. of Biosyst. and Agric. Eng., Oklahoma State Univ., Stillwater, OK 74078. Contribution from the Oklahoma Agric. Exp. Stn. Received 7 Aug. 2001. *Corresponding author (wrr@mail.pss. okstate.edu)

Published in Agron. J. 94:815-820 (2002). and $>10 \%$ in corn (Hilton et al., 1994). Fertilizer N losses due to surface runoff range between 1 and $13 \%$ (Blevins et al., 1996; Chichester and Richardson, 1992). Urea fertilizers applied to the surface without incorporation can result in $\mathrm{NH}_{3}$ volatilization losses in excess of 40\% (Fowler and Brydon, 1989; Hargrove et al., 1977). In cooler temperate climates, $\mathrm{NO}_{3}$ losses through tile drainage have approached $26 \mathrm{~kg} \mathrm{~N}^{-1} \mathrm{yr}^{-1}$, or $23 \%$ of the total $\mathrm{N}$ applied (Drury et al., 1996). In general, loss of $\mathrm{N}$ only occurs when mineral $\mathrm{N}\left(\mathrm{NH}_{4}\right.$ and $\mathrm{NO}_{3}$ ) are present in excess of plant needs (Johnson and Raun, 1995).

\section{Spatial Scale of Nitrogen Availability}

Conventional $\mathrm{N}$ fertilization practices apply a single rate over areas of tens to hundreds of hectares before the crop is planted. Following extensive soil sampling, optical sensor measurements of plants, and geostatistical analyses, we determined that the spatial scale of $\mathrm{N}$ availability was at $1 \mathrm{~m}^{2}$ and that each square meter needed to be treated independently (Raun et al., 1998; Solie et al., 1999). This contrasts with the 1-ha-grid soil sampling currently promoted in precision agriculture. At a typical cost of $\$ 10.00$ per sample for soil analyses, soil sampling to manage at the meter level is impractical.

\section{Response Index}

Evaluation of grain yield response to $\mathrm{N}$ fertilization in 15-yr corn and 30-yr wheat experiments has shown that check plots where no $\mathrm{N}$ has been applied exhibit wide variation in the supply of soil $\mathrm{N}$ from year to year (Johnson and Raun, unpublished, 2002). This temporal dependence of $\mathrm{N}$ availability reinforces the need for midseason measurements that account for $\mathrm{N}$ supplied through mineralization. Raun et al. (2001) developed an index to predict potential grain yields with no added fertilization $\left(\mathrm{YP}_{0}\right)$. However, it was necessary to determine the potential yield increase that could be achieved from in-season applications of fertilizer $\mathrm{N}$. This work led to the development of a fertilizer response index (RI) that was calculated by dividing average normalized difference vegetation index (NDVI) from a non-N-limiting strip (created in each field by fertilizing a strip at a rate where $\mathrm{N}$ would not be limiting throughout the season) by the average NDVI in a parallel strip that is

Abbreviations: GDD, growing degree days; INSEY, in-season estimated grain yield; NDVI, normalized difference vegetation index; NFOA, nitrogen fertilization optimization algorithm; NUE, nitrogen use efficiency; RI, response index; $\mathrm{RI}_{\mathrm{NDV}}$, in-season response index; $\mathrm{RI}_{\text {HARVEST, }}$, response index at harvest; $\mathrm{YP}_{0}$, potential yield with no added fertilization; $\mathrm{YP}_{\mathrm{MAX}}$, maximum obtainable yield; $\mathrm{YP}_{\mathrm{N}}$, potential yield with added $\mathrm{N}$ fertilization. 
representative of the $\mathrm{N}$ availability across the field as affected by $\mathrm{N}$ fertilizer applied by the farmer (Johnson and Raun, unpublished, 2002). Farmer N fertilization practices could result in zero $\mathrm{N}$ availability to non- $\mathrm{N}$ limiting conditions; thus, the initial preplant non-N-limiting strip would likely range anywhere from 20 to 100 $\mathrm{kg} \mathrm{N} \mathrm{ha}{ }^{-1}$. Computing RI will thus require the addition of a non-N-limiting strip in each field where NDVI from that strip will be divided by NDVI from any strip in the rest of the field receiving the fixed preplant $\mathrm{N}$ rate of the farmer. This quantitative RI is in turn multiplied by the predicted $\mathrm{YP}_{0}$ to determine the potential yield with added $\mathrm{N}$ fertilization $\left(\mathrm{YP}_{\mathrm{N}}\right)$.

\section{Nitrogen Fertilization Optimization Algorithm}

By knowing the quantitative response to fertilizer $\mathrm{N}$ achievable for a given area, the $\mathrm{N}$ fertilization optimization algorithm (NFOA) was developed to determine the prescribed $\mathrm{N}$ rate needed for each $1 \mathrm{~m}^{2}$ based on predicted $\mathrm{YP}_{0}$ and the specific RI for each field. The NFOA accounts for spatially variable potential yield, early season $\mathrm{N}$ uptake, and responsiveness of the crop to $\mathrm{N}$ input. Stepwise algorithm calculations are as follows:

1. Predict $\mathrm{YP}_{0}$ from the equation for grain yield and in-season estimates of grain yield (INSEY), where INSEY = NDVI (Feekes 4-6)/days from planting where growing degree days $($ GDD $)>0$ GDD $=($ Tmin + Tmax) $/ 2-4.4^{\circ} \mathrm{C}$, where Tmin and Tmax represent daily ambient low and high temperatures]. Lukina et al. (2001) showed that a single equation could be used to predict grain yield over a wide production range (0.5-6.0 $\mathrm{Mg} / \mathrm{ha}$ ), diverse sites, and with differing planting and harvest dates.

2. Predict the magnitude of response to $\mathrm{N}$ fertilization, in-season RI ( $\left.\mathrm{RI}_{\mathrm{NDVI}}\right)$, computed as: NDVI collected from growing winter wheat anytime from Feekes 4 to Feekes 6 in non-N-limiting fertilized plots divided by NDVI Feekes 4 to Feekes 6 in a parallel strip receiving the farmer preplant $\mathrm{N}$ rate. The $\mathrm{RI}_{\mathrm{NDVI}}$ has been found to be highly correlated with the RI at harvest ( $\left.\mathrm{RI}_{\text {HARVEST }}\right)$, which is similarly computed by dividing the grain yield from the non-N-limiting fertilized plots by the yield from plots receiving the farmer preplant $\mathrm{N}$ rate (Mullen et al., 2001). The farmer preplant $\mathrm{N}$ rate could range anywhere from zero to a rate applied for non-N-limiting conditions.

3. Determine the predicted $\mathrm{YP}_{\mathrm{N}}$ based both on the $\mathrm{RI}_{\mathrm{NDVI}}$ and the $\mathrm{YP}_{0}$ as follows:

$$
\mathrm{YP}_{\mathrm{N}}=\mathrm{YP}_{0} \times \mathrm{RI}_{\mathrm{NDVI}}
$$

$\mathrm{RI}_{\mathrm{NDVI}}$ was limited so as not to exceed 2.0, and $\mathrm{YP}_{\mathrm{N}}$ was similarly limited not to exceed the maximum obtainable yield $\left(\mathrm{YP}_{\mathrm{MAX}}\right)$. The $\mathrm{YP}_{\mathrm{MAX}}$ was determined by the farmer or previously defined as a biological maximum for a specific cereal crop grown within a specific region and under defined management practices (e.g., $\mathrm{YP}_{\mathrm{MAX}}$ for dryland winter wheat produced in central Oklahoma would be $7.0 \mathrm{Mg} / \mathrm{ha}$ ). The $\mathrm{RI}_{\mathrm{NDVI}}$ was capped at 2.0 as in-season applications of $\mathrm{N}$ would unlikely lead to $\mathrm{YP}_{\mathrm{N}}$ being more than two times greater than baseline $\mathrm{YP}_{0}$.
4. Predict percent $\mathrm{N}$ in the grain (PNG) based on $\mathrm{YP}_{\mathrm{N}}$ that includes inverse relation to yield level:

$$
\mathrm{PNG}=b_{0}+b_{1} \times \mathrm{YP}_{\mathrm{N}}
$$

5. Calculate predicted grain $\mathrm{N}$ uptake (GNUP), predicted percent $\mathrm{N}$ in the grain multiplied by $\mathrm{YP}_{\mathrm{N}}$ :

$$
\mathrm{GNUP}=\mathrm{YP}_{\mathrm{N}} \times \mathrm{PNG}
$$

6. Calculate predicted forage $\mathrm{N}$ uptake (FNUP) from NDVI:

$$
\mathrm{FNUP}=b_{0}+b_{1} \mathrm{e}^{\mathrm{b} 2 \mathrm{NDVI}}
$$

7. Determine in-season fertilizer $\mathrm{N}$ requirement (FNR):

$$
\mathrm{FNR}=(\text { GNUP }- \text { FNUP }) / 0.70
$$

A divisor of 0.70 is used because the theoretical maximum NUE of an in-season $\mathrm{N}$ application is approximately $70 \%$.

The use of active growing days from planting and NDVI (estimate of total $\mathrm{N}$ uptake, biomass, or both biomass) in computing INSEY allows integration of the effects of both winter and spring growing conditions and date of planting. The INSEY index is essentially the rate of $\mathrm{N}$ uptake (kilograms of forage $\mathrm{N}$ assimilated per day) by the plant. This approach is consistent with work showing the relationship between aboveground plant dry weight and cumulative GDD (Rickman et al., 1996). The objective of the current study was to determine the validity using INSEY (Lukina et al., 2001; Raun et al., 2001) and NFOA to modulate N midseason at $1-\mathrm{m}^{2}$ spatial resolution.

\section{MATERIALS AND METHODS}

Early on in this project, we noted the need to develop a sensing system capable of predicting potential forage $\mathrm{N}$ uptake (Stone et al., 1996) and wheat grain yields at meter-level spatial resolution. The strategy we investigated relies on remotely sensed spectral reflectance measurements to estimate plant $\mathrm{N}$ uptake and eventual yield. These estimates are used to modulate the addition of $\mathrm{N}$ fertilizer during early growth stages of the plant [between Feekes 4 and 6 (Large, 1954)]. Our initial index for INSEY was computed by dividing NDVI \{NDVI = $\left[\left(\mathrm{NIR}_{\mathrm{ref}} / \mathrm{NIR}_{\text {inc }}\right)-\left(\operatorname{Red}_{\mathrm{ref}} / \operatorname{Red}_{\text {inc }}\right)\right] /\left[\left(\mathrm{NIR}_{\mathrm{ref}} / \mathrm{NIR}_{\text {inc }}\right)+\left(\operatorname{Red}_{\mathrm{ref}} /\right.\right.$ $\left.\operatorname{Red}_{\text {inc }}\right)$ ], where $\mathrm{NIR}_{\text {ref }}$ and $\mathrm{Red}_{\mathrm{ref}}=$ magnitude of reflected light and $\mathrm{NIR}_{\text {inc }}$ and $\mathrm{Red}_{\text {inc }}=$ magnitude of incident light $\}$ by

\begin{tabular}{|c|c|c|c|c|}
\hline Treatment & Preplant $\mathbf{N}$ & Midseason N & $\begin{array}{c}\text { Yield potential } \\
\text { estimated }\end{array}$ & $\begin{array}{l}\text { Fertilizer } \\
\text { application } \\
\text { resolution }\end{array}$ \\
\hline & \multicolumn{2}{|c|}{$\mathrm{kg} \mathrm{ha}^{-1}$} & & $\mathbf{m}^{2}$ \\
\hline 1 & 0 & 0 & no & - \\
\hline 2 & 0 & 45 & no & 24 \\
\hline 3 & $\mathbf{0}$ & 90 & no & 24 \\
\hline 4 & 45 & 45 & no & 24 \\
\hline 5 & 90 & 0 & no & 24 \\
\hline 6 & 0 & NFOA $\uparrow$ & yes & 1 \\
\hline 7 & $\mathbf{0}$ & one-half NFOA & yes & 1 \\
\hline 8 & 45 & NFOA & yes & 1 \\
\hline
\end{tabular}
the number of days from planting to sensing (Raun et al., 2001). This index was shown to be a reliable midseason pre-

Table 1. Treatment structure for winter wheat experiments at four locations, 2000-2001.

† NFOA, topdress $\mathbf{N}$ rates determined employing estimated yield potentia using the nitrogen fertilizer optimization algorithm. 
dictor of final grain yield over 16 locations in Oklahoma and seven in Virginia.

Four winter wheat experiments were established in the fall of 2000. Locations and associated soils were Chickasha, OK, Dale silt loam (fine-silty, mixed, superactive, thermic Pachic Haplustoll); Perkins, OK, Teller sandy loam (fine-loamy, mixed, thermic Udic Argiustolls); Covington, OK, Renfrow silt loam (fine, mixed, thermic Vertic Paleustolls); and Lahoma, OK, Grant silt loam (fine-silty, mixed, thermic Udic Argiustolls). Treatment structure is reported in Table 1. All field experiments used a randomized complete block design with four replications. Plot size was 6 by $4 \mathrm{~m}$. For Treatments 1 through 5 , the entire plot area $\left(24 \mathrm{~m}^{2}\right)$ was treated with a uniform $\mathrm{N}$ rate. For Treatments 6 through 8, each $1-\mathrm{m}^{2}$ area within the $24-\mathrm{m}^{2}$ main plot was sensed and treated independently. Field plot activities and initial composite soil test levels are reported in Table 2.

Collection of spectral reflectance from each $1 \mathrm{~m}^{2}$, computation of NDVI, and optical sensors used were consistent with past work (Raun et al., 2001). All NDVI calculations were made with measurements taken using a hand-held multispectral reflectance optical sensor designed and fabricated at Oklahoma State University. The optical sensor simultaneously measured incident and reflected light from the plant at $671 \pm$ 6 and $780 \pm 6 \mathrm{~nm}$. The NDVI calculations based on reflectance levels have been shown to be an excellent predictor of total plant N uptake (Feekes growth stages 4-9). Varietal differences were not targeted because of limited differences in postdormancy NDVI readings for common varieties grown in this region (Sembiring et al., 2000). Reflectance readings from all experiments were collected between February and April and ranged from 136 to $153 \mathrm{~d}$ after planting. At all locations, winter wheat was optically sensed between Feekes physiological growth stage 4 (leaf sheaths beginning to lengthen) and 6 (first node of stem visible) (Large, 1954).

Ammonium nitrate was applied within $7 \mathrm{~d}$ of sensing for Treatments 2 through 4 and 6 through 8 (Table 1). The NFOA was used to determine $\mathrm{N}$ rates for each $1 \mathrm{~m}^{2}$ for Treatments 6,7 , and 8 . Wheat was harvested in early June at all locations. Grain subsamples from each plot were ground to pass a 140 mesh screen, and total $\mathrm{N}$ in grain was analyzed using a Carlo Erba NA-1500 dry combustion analyzer (Schepers et al., 1989).

\section{RESULTS}

Grain yield means, $\mathrm{RI}_{\mathrm{NDVI}}$, and $\mathrm{RI}_{\mathrm{HARVEST}}$ are reported by treatment and location in Table 3 . The standard error of the difference (SED) between two equally replicated means is reported by site. Wheat grain yield levels at the four sites included in this work were close to the state average of $2016 \mathrm{~kg} \mathrm{ha}^{-1}\left(30 \mathrm{bu} \mathrm{ac}^{-1}\right)$ over the past $5 \mathrm{yr}$. The four locations (over $1 \mathrm{yr}$ ) represented different environments where NFOA was being tested, thus allowing us to test whether or not the concept was unique to a single environment or transcending environments.

At Lahoma and Perkins, wheat was planted late due to dry fall conditions. At all sites, severe cold was encountered in December and January, thus restricting winter growth. Spring growing conditions were good, characterized by adequate and timely rainfall, limited disease, and no frost damage.

Large differences in forage $\mathrm{N}$ uptake (accurately predicted using NDVI; Lukina et al., 2001) were noted at all sites, and these differences produced large disparity in the minimum and maximum $\mathrm{N}$ rates applied, which were determined using the NFOA (Treatments 6,7 , and 8; Table 4). For Treatment 6 (all fertilizer applied midseason, variable rate), at Covington, the minimum was 32.4 and the maximum $102.8 \mathrm{~kg} \mathrm{~N} \mathrm{ha}^{-1}$. This is a broad range considering that it comes from ninety-six $1-\mathrm{m}^{2}$ subplots (four replications, $24-\mathrm{m}^{2}$ plot size). Similarly, a wide range was noted at the other sites, indicative of large spatial variability within relatively small areas.

At three of the four sites (exception was Perkins), a significant response in grain yield was observed as a result of applying $\mathrm{N}$ (Table 3 ). The importance of applying preplant fertilizer to maximize yields was evident when comparing results from the $45 \mathrm{~kg} \mathrm{~N} \mathrm{ha}^{-1}$ preplant + midseason NFOA (Treatment 8 ) with those where all $\mathrm{N}$ was applied midseason (Treatments 2 and 3; Table 3).

Results from the four sites confirmed previous work showing that yield potential could be accurately predicted (Raun et al., 2001). At Chickasha, low $\mathrm{YP}_{0}$ and a limited response to $\mathrm{N}$ were projected. As a result, NFOA predicted that yields would be maximized at low midseason $\mathrm{N}$ rates, which was in fact observed (Table

Table 2. Field plot activities and soil characteristics for experiments where $\mathbf{N}$ was applied based on in-season estimated yield (INSEY) at four locations, 2000-2001.

\begin{tabular}{|c|c|c|c|c|}
\hline \multirow[b]{2}{*}{ Plot activity } & \multicolumn{4}{|c|}{ Location } \\
\hline & Chickasha & Perkins & Covington & Lahoma \\
\hline Planting date & 3 Oct. 2000 & 17 Nov. 2000 & 1 Oct. 2000 & 27 Nov. 2000 \\
\hline Variety & Custer & Custer & Coker & Custer \\
\hline Seeding rate, $\mathrm{kg} \mathrm{ha}^{-1}$ & 67 & 76 & 54 & 76 \\
\hline Sensor date & 6 Mar. 2001 & 16 Apr. 2001 & 16 Feb. 2001 & 13 Apr. 2001 \\
\hline Days from planting to sensing & 153 & 149 & 137 & 136 \\
\hline Days from planting to sensing $($ GDD $>0) \dagger$ & 116 & 76 & 69 & 60 \\
\hline Preplant fertilization date & 2 Oct. 2000 & 16 Nov. 2000 & 13 Sept. 2000 & 27 Nov. 2000 \\
\hline Midseason fertilization date & 13 Mar. 2001 & 18 Apr. 2001 & 22 Feb. 2001 & 19 Apr. 2001 \\
\hline Harvest date & 5 June 2001 & 7 June 2001 & 13 June 2001 & 14 June 2001 \\
\hline Soil pH & 7.1 & 5.9 & 6.1 & 5.6 \\
\hline Organic $\mathbf{C}, \mathbf{g ~ k g}^{-1}$ & 12.3 & 7.0 & 9.9 & 8.6 \\
\hline Total $\mathbf{N}, \mathbf{g ~ k g}^{-1}$ & 1.10 & 0.67 & 1.05 & 0.92 \\
\hline $\mathbf{P}, \mathbf{m g ~ \mathbf { ~ k g } ^ { - 1 }}$ & 66 & 19 & 21 & 45 \\
\hline $\mathbf{K}, \mathbf{m g ~ k g} \mathbf{~ g}^{-1}$ & 443 & 181 & 345 & 410 \\
\hline $\mathrm{NH}_{4}-\mathbf{N}, \mathrm{mg} \mathrm{kg}^{-1}$ & 18.5 & 2.6 & 6.1 & 3.8 \\
\hline $\mathrm{NO}_{3}-\mathrm{N}, \mathrm{mg} \mathrm{kg}^{-1}$ & 9.2 & 2.7 & 1.4 & 2.8 \\
\hline Preplant $\mathbf{P}$ fertilizer applied, $\mathrm{kg} \mathrm{ha}^{-1}$ & $\mathbf{0}$ & 39 & 39 & 0 \\
\hline
\end{tabular}

$\dagger$ GDD $>0$ = growing degree days where values were positive. 
Table 3. Wheat grain yield response to applied $\mathbf{N}$ at fixed rates and rates based on in-season estimated yield (INSEY) at four locations, 2001.

\begin{tabular}{|c|c|c|c|c|c|c|c|c|c|}
\hline \multirow[b]{2}{*}{ Trt } & \multirow[b]{2}{*}{$\mathbf{N}$ rate } & \multirow[b]{2}{*}{ Method } & \multicolumn{4}{|c|}{ Grain Yield } & \multirow{2}{*}{$\begin{array}{l}\text { Grain yield } \dagger \\
\text { avg. }\end{array}$} & \multirow{2}{*}{$\begin{array}{l}\text { Revenue } \dagger \\
\text { avg. }\end{array}$} & \multirow{2}{*}{$\begin{array}{l}\text { NUE }+ \text { : } \\
\text { avg. }\end{array}$} \\
\hline & & & Chickasha & Perkins & Covington & Lahoma & & & \\
\hline \multicolumn{3}{|c|}{$\mathbf{k g ~ h a ~}^{-1}$} & \multicolumn{4}{|c|}{$\mathrm{kg} \mathrm{ha}^{-1}$} & $\mathbf{k g ~ h a ~}^{-1}$ & $\$ \mathbf{h a}^{-1}$ & $\%$ \\
\hline 1 & o & check & 1033 & 1274 & 1562 & 951 & 1182 & 118 & - \\
\hline 2 & 45 & midseason & 1381 & 1353 & 1994 & 1312 & 1562 & 131 & 25 \\
\hline 3 & 90 & midseason & 1438 & 1367 & 2461 & 1533 & 1810 & 132 & 17 \\
\hline 4 & 90 & 45 preplant, 45 midseason & 1677 & 1607 & 2744 & 1894 & 2105 & 161 & 22 \\
\hline 5 & 90 & preplant & 1776 & 1592 & 2329 & 2084 & 2063 & 157 & 22 \\
\hline 5 & $\S$ & midseason NFOA & $1410(19.8)$ & $1246(58.4)$ & 2553 (58.6) & $1542(50.9)$ & 1835 (43.1) & 160 & 40 \\
\hline 7 & $\S$ & midseason one-half NFOA & 1197 (9.7) & 1396 (33.4) & $1966(33.8)$ & $1696(24.4)$ & 1619 (22.6) & 149 & $\mathbf{5 0}$ \\
\hline 8 & $45+\S$ & 45 preplant, mid-season-NFOA & 1784 (15.4) & 1519 (66.2) & $3269(104.3)$ & 1823 (67.9) & $2292(62.5)$ & 170 & 23 \\
\hline \multirow{2}{*}{\multicolumn{3}{|c|}{$\begin{array}{l}\text { Contrast } \\
\text { N rate }\end{array}$}} & & & & & & & \\
\hline & & & I & NS & $* *$ & * & - & - & - \\
\hline \multirow{2}{*}{\multicolumn{3}{|c|}{$\begin{array}{l}\mathbf{R I}_{\text {NDVI }}^{\#} \\
\mathbf{R I}_{\text {HARVEST }} \dagger \dagger\end{array}$}} & 1.27 & 1.48 & 1.39 & 2.22 & - & - & - \\
\hline & & & 1.72 & 1.26 & 1.76 & 2.19 & - & - & - \\
\hline \multirow{2}{*}{\multicolumn{3}{|c|}{$\begin{array}{l}\mathbf{Y P}_{0} \text { (avg.) }+\uparrow \\
\text { Yield (avg.) } \S \S\end{array}$}} & 1605 & 2585 & 2527 & 1272 & - & - & - \\
\hline & & & 1460 & 1418 & 2287 & 1604 & - & - & - \\
\hline \multicolumn{3}{|c|}{ SEDIII } & 179 & 138 & 207 & 200 & 201 & 20 & 12 \\
\hline
\end{tabular}

* Significant at the 0.05 probability level.

** Significant at the 0.01 probability level.

$\dagger$ Excludes Perkins where no response to applied $\mathbf{N}$ was observed.

$\$ \mathbf{N U E}=$ nitrogen use efficiency, estimated by subtracting $\mathbf{N}$ removed (grain yield times total $\mathbf{N}$ ) in the grain in zero- $\mathbf{N}$ plots from that found in plots receiving added $\mathbf{N}$, divided by the rate of $\mathbf{N}$ applied.

$\S$ Average midseason $\mathbf{N}$ rate applied.

II Significant at the 0.10 probability level.

\# $\mathbf{R I}_{\mathrm{NDVI}}=$ in-season response index, computed by dividing the average normalized difference vegetation index (NDVI) at Feekes 4 through 6 from

Treatment 5 by the check (no preplant applied).

H $\mathbf{I I}_{\text {HARVEST }}$ = response index at harvest, computed by dividing the highest yield of $\mathbf{N}$ fertilized plots by the yield of unfertilized control plots.

$+\mathbf{Y P}_{0}$ (avg.) = predicted grain yield with no added fertilization (from INSEY for Treatments 6, 7, and 8).

$\S \S$ Yield (avg.) = average yield of all treatments, by site.

III SED = standard error of the difference between two equally replicated means.

3). Yields were maximized for Treatment $8(45 \mathrm{~kg} \mathrm{~N}$ $\mathrm{ha}^{-1}$ preplant + midseason $\mathrm{N}$, variable applied, for yield of $\left.1784 \mathrm{~kg} \mathrm{ha}^{-1}\right)$ compared with Treatment $4(45 \mathrm{~kg} \mathrm{~N}$ $\mathrm{ha}^{-1}$ preplant $+45 \mathrm{~kg} \mathrm{~N} \mathrm{ha}^{-1}$ midseason, for yield of $1677 \mathrm{~kg} \mathrm{ha}^{-1}$ ) where an additional $29 \mathrm{~kg} \mathrm{~N} \mathrm{ha}^{-1}$ was applied with no associated yield increase. Similarly, comparing the yields obtained from midseason-only treatments, it is apparent that Treatment 6 (all fertilizer applied midseason, variable rate average of $19.8 \mathrm{~kg} \mathrm{~N}$ $\mathrm{ha}^{-1}$ ) was equal in yield to that obtained when either 45 or $90 \mathrm{~kg} \mathrm{~N} \mathrm{ha}^{-1}$ as a fixed rate was applied midseason (Treatments 2 and 3 ).

At the Perkins site, the sandy loam soil dries out quickly without timely rain, and lower soil-moisture storage becomes more yield limiting than the silt loam soils at the other sites; thus, measured grain yields were lower than predicted. This anomaly has been confirmed by other studies at this site (Raun et al., 2001). In addition, predicted response to applied $\mathrm{N}$ from in-season NDVI measurements was overestimated by $\mathrm{RI}_{\mathrm{NDVI}}$ at this site, likely due to limiting moisture at anthesis that restricted response to other adequately supplied growth factors. Because no yield response to $\mathrm{N}$ was noted, it was not included in the average estimates of revenue and NUE in Table 3.

Higher yields and response to midseason $\mathrm{N}$ were predicted and observed at Covington. At this site, a higher $\mathrm{N}$ need was calculated (104.3 $\mathrm{kg} \mathrm{N}^{-1}$, Treatment 8) than what farmers would normally apply midseason. It was therefore encouraging to find that this added $\mathrm{N}$ resulted in increased grain yield $\left(3269 \mathrm{~kg} \mathrm{ha}^{-1}\right.$, Treatment 8, vs. $2744 \mathrm{~kg} \mathrm{ha}^{-1}$, Treatment 4). Projecting whether or not a response to applied $\mathrm{N}$ could be achieved is critical to this work. Excluding Perkins, the predicted response to applied $\mathrm{N}$ using optical sensor measurements $\left(\mathrm{RI}_{\mathrm{NDVI}}\right)$ in early spring was positively correlated with grain yield response that could be attributed to applied $\mathrm{N}$ in the harvested grain $\left(\mathrm{RI}_{\text {HARVEST }}\right)$.

For the four sites evaluated, the largest difference in plant growth due to preplant $\mathrm{N}$ nutrition was predicted to take place at Lahoma from in-season NDVI measurements, and that was confirmed at harvest, 2 mo later ( $0 \mathrm{~N}$ vs. $90 \mathrm{~kg} \mathrm{~N} \mathrm{ha}^{-1}$ preplant). Wheat growth in Treatments $2,3,6$, and 7 was similar, and notably poor in early April when yield potential was sensed, because none of these treatments received preplant N. The RI

Table 4. Average, minimum, and maximum midseason $\mathbf{N}$ rates applied to three treatments employing the $\mathbf{N}$ fertilization optimization algorithm (NFOA), with a preplant $\mathrm{N}$ application variable.

\begin{tabular}{|c|c|c|c|c|c|c|c|c|c|}
\hline \multirow[b]{2}{*}{ Location } & \multicolumn{3}{|c|}{ Treatment 6 (NFOA) } & \multicolumn{3}{|c|}{ Treatment 7 (one-half NFOA) } & \multicolumn{3}{|c|}{ Treatment $8\left(45 \mathrm{~kg} \mathrm{~N} \mathrm{ha}^{-1}+\right.$ NFOA $)$} \\
\hline & Avg. & Min. & Max. & Avg. & Min. & Max. & Avg. & Min. & Max. \\
\hline & & & & & kg ha & & & & \\
\hline Chickasha & 19.8 & 10.8 & 22.0 & 9.9 & 7.2 & 10.9 & 16.0 & 0.02 & 21.9 \\
\hline Perkins & 58.4 & 31.9 & 86.9 & 33.4 & 17.3 & 43.4 & 66.2 & 32.8 & 86.9 \\
\hline Covington & 58.6 & 32.4 & 102.8 & 33.8 & 14.6 & 70.0 & 104.3 & 36.1 & 233.5 \\
\hline Lahoma & 50.9 & 38.4 & 75.9 & 24.4 & 20.6 & 36.6 & 67.9 & 44.8 & 109.2 \\
\hline
\end{tabular}


predicted the magnitude of an achievable $\mathrm{N}$ response because yields were nearly double from midseasonapplied $\mathrm{N}\left(\mathrm{RI}_{\mathrm{NDVI}}\right.$ of 2.22 and an $\mathrm{RI}_{\mathrm{HARVEST}}$ of 2.19). Having the ability to predict that yields can be doubled if midseason $\mathrm{N}$ is applied is in itself a powerful tool. Furthermore, it is equally important to know how much $\mathrm{N}$ to apply to achieve that doubling of yields. At the Lahoma site, $50.9 \mathrm{~kg} \mathrm{~N} \mathrm{ha}^{-1}$ (spatially applied) was needed to produce yields projected with $\mathrm{RI}_{\mathrm{NDVI}}$, equal to $90 \mathrm{~kg} \mathrm{~N}$ ha $^{-1}$ applied midseason (Treatment 6 vs. Treatment 3; Table 3). Applying the NFOA enables the determination of yield increases possible via midseason application of $\mathrm{N}$, and it allows us to estimate how much $\mathrm{N}$ is needed to obtain that projected yield. Although applying all of the $\mathrm{N}$ preplant (Treatment 5) produced maximum yields at this site, this management practice requires that farmers take more risk. Once a good plant stand is secured (dryland wheat production is highly dependent on rainfall soon after planting), added fertilizer inputs can be tailored to what is made possible by the growing environment.

Averaged over the three sites with $\mathrm{N}$ response, when all $\mathrm{N}$ was applied midseason based on NFOA (Treatment 6), grain yields were increased $\left(+273 \mathrm{~kg} \mathrm{ha}^{-1}\right)$ compared with a similar single rate, using similar fertilizer $\mathrm{N}$ rates (43.1 vs. $45 \mathrm{~kg} \mathrm{~N}^{-1}$, Treatment 2). At $\$ 0.10 \mathrm{~kg}^{-1}$ of wheat grain, this would have a value of $\$ 27.30 \mathrm{ha}^{-1}$. When comparing Treatment 6 (all fertilizer applied midseason, variable rate) with a much higher single $\mathrm{N}$ rate of $90 \mathrm{~kg} \mathrm{~N}^{-1}$ applied midseason (Treatment 3), the same amount of grain was produced, but $46.9 \mathrm{~kg} \mathrm{ha}^{-1}$ less $\mathrm{N}$ was used in Treatment 6 . At $\$ 0.55$ $\mathrm{kg}^{-1} \mathrm{~N}$, the savings in fertilizer $\mathrm{N}$ would have a value of $\$ 25.79 \mathrm{ha}^{-1}$. Similar results were noted when onehalf of the $\mathrm{N}$ rate $\left(22.6 \mathrm{~kg} \mathrm{~N} \mathrm{ha}^{-1}\right)$ predicted using NFOA was applied, producing $1619 \mathrm{~kg} \mathrm{ha}^{-1}$ grain contrasted with a grain yield of $1562 \mathrm{~kg} \mathrm{ha}^{-1}$ and $45 \mathrm{~kg} \mathrm{~N}$ $\mathrm{ha}^{-1}$ applied at a single rate (Treatment 7 vs. Treatment 2).

Simple estimates of revenue (averaged over the three sites where significant differences due to treatment were observed) for all treatments are reported in Table 3 (grain revenue minus fertilizer costs). Using the same values for grain and fertilizer previously reported, Treatment $8\left(45 \mathrm{~kg} \mathrm{~N}^{-1}\right.$ preplant + midseason $\mathrm{N}$ variably applied) increased revenue by more than $\$ 9.00$ over all other treatments but required $17.5 \mathrm{~kg} \mathrm{ha}^{-1}(45+62.5=$ 107.5) more $\mathrm{N}$ compared with an average $\mathrm{N}$ rate of $90 \mathrm{~kg}$ $\mathrm{ha}^{-1}$ (applied preplant, split, or all midseason). Similar benefits of Treatment 6 , which used NFOA, can be seen over both the 45 and $90 \mathrm{~kg} \mathrm{~N}^{-1}$ midseason single rates (Treatments 2 and 3 ), increasing revenue by more than $\$ 28.00 \mathrm{ha}^{-1}$ while using less fertilizer $\mathrm{N}$. Treatments 2,3 , and 6 received all $\mathrm{N}$ midseason, the only difference being that Treatment 6 received $\mathrm{N}$ spatially applied to each $1 \mathrm{~m}^{2}$. In either scenario, this increased income will more than cover the increased technology costs, expected to be somewhere between $\$ 4.00$ and $\$ 5.00$ $\mathrm{ha}^{-1}$. We expect the greatest economic benefit for this practice to occur under conditions of high and spatially varying $\mathrm{N}$ stress.
Estimates of NUE were determined by subtracting $\mathrm{N}$ removed (grain yield times total $\mathrm{N}$ ) in the grain of zero-N plots from that found in plots receiving added $\mathrm{N}$ and dividing by the rate of $\mathrm{N}$ applied. Averaged over locations, NUE was improved by $>15 \%$ when comparing Treatment 2 with Treatment 6 where similar rates were applied. All of the treatments that employed NFOA (Treatments 6,7, and 8) resulted in equal or increased NUE compared with any of the single-rate combinations (Treatments 2-5). The environmental benefit of this increased NUE cannot be determined but is considered important.

\section{DISCUSSION}

Placing a biological limit on $\mathrm{YP}_{\mathrm{MAX}}$ is necessary if a similar NFOA will be applied in other regions with other crops, soils, and differing management (tillage, irrigation, etc.) practices. For example, maximum yields for hard red winter wheat under dryland production in central Oklahoma will seldom exceed 7.0 $\mathrm{Mg} \mathrm{ha}^{-1}$ (103 $\left.\mathrm{bu} \mathrm{ac}^{-1}\right)$. Alternatively, winter wheat grain yields under irrigation in western Oklahoma can reach $11 \mathrm{Mg} \mathrm{ha}^{-1}$ $\left(162 \mathrm{bu} \mathrm{ac}^{-1}\right)$. Because the NFOA depends on predicted yield, it is critical that we apply reasonable agronomic limits on what would be a likely result under optimum management.

The $\mathrm{RI}_{\mathrm{NDVI}}$ accounts for both the likelihood of obtaining a response to in-season applied $\mathrm{N}$ and the magnitude of the response to applied $\mathrm{N}$ at a given level of $\mathrm{YP}_{0}$. The predicted $\mathrm{YP}_{\mathrm{N}}\left(\mathrm{YP}_{\mathrm{N}}=\mathrm{YP}_{0} \times \mathrm{RI}_{\mathrm{NDVI}}\right)$ will generally not be more than double $\mathrm{YP}_{0}$. Because it would be unlikely to double yields $\left(\mathrm{YP}_{0}\right)$ from in-season applied $\mathrm{N}\left(\mathrm{YP}_{\mathrm{N}}\right)$, we placed a limit of 2.0 on $\mathrm{RI}_{\mathrm{NDVI}}$. In this regard, $\mathrm{YP}_{\mathrm{MAX}}$ is needed to place limits on $\mathrm{YP}_{\mathrm{N}}$ in those cases where $\mathrm{YP}_{\mathrm{N}}$ may exceed the biological limits previously documented for specific environments. An exception to the RI limit of 2 would be expected in environments conducive to high $\mathrm{N}$ immobilization (e.g., no-till) or small contributions from $\mathrm{N}$ mineralization (e.g., irrigated desert soils).

A prototype of a commercial-scale variable $\mathrm{N}$ rate applicator that employs the concepts discussed in this paper has been developed (www.ntechindustries.com; verified 21 Mar. 2002). Implementation of the NFOA concept requires collecting midseason NDVI measurements from optical sensors mounted ahead of each fertilization nozzle and prescribing fertilizer rates computed on the go for each $1-\mathrm{m}^{2}$ area. The optical sensorbased $\mathrm{N}$ fertilizer applicator is equipped with a GPS receiver for postprocessed georeferencing of all optical sensor data. For each field, farmers will provide the date of planting to compute INSEY (NDVI/days from planting where GDD > 0) on the go. Growing degree day data is available to growers through various means. Just before planting, a non-N-limiting strip will be applied in each field. If farmers apply preplant $\mathrm{N}$ at a lower rate, or if they do not apply fertilizer at all, the non-N-limiting strip will be used to later establish a fieldspecific $\mathrm{RI}_{\mathrm{NDVI}}$. Before applying midseason fertilizer, the 
non-N-limiting strip will be optically sensed adjacent to the farmer practice to determine the field-specific $\mathrm{RI}_{\mathrm{NDVI}}$.

Improvement in fertilizer NUE beyond the promising results of these experiments may be possible from foliar applications of urea ammonium nitrate solutions (common liquid $\mathrm{N}$ fertilizer used for in-season applications) and by variable $\mathrm{N}$ rate application. Granular $\mathrm{NH}_{4} \mathrm{NO}_{3}$ fertilizer applied to each $1 \mathrm{~m}^{2}$ reported here likely would have decreased NUE because unlike foliar-applied N, it would be subject to surface runoff, microbial immobilization, volatilization, and denitrification before being absorbed by plant roots.

This study demonstrates that crop reflectance measurements using optical sensors can be used to set more efficient and profitable fertilization levels. The techniques that have been developed are appropriately applied at spatial scales of $1 \mathrm{~m}^{2}$ and will require variable rate applicators equipped with optical sensors. The techniques rely on non-N-limiting test strips in fields that allow an in-season estimate of fertilizer response. The use of NFOA may eventually replace $\mathrm{N}$ fertilization rates determined using production history (yield goals), provided that the production system allows for in-season application of fertilizer N. Fertilizing each $1-\mathrm{m}^{2}$ area based on midseason estimates of grain yield and the likelihood of achieving a response to added fertilizer could lead to improved NUE in cereal grain crops.

\section{REFERENCES}

Aulakh, M.S., D.A. Rennie, and E.A. Paul. 1982. Gaseous nitrogen losses from cropped and summer fallowed soils. Can. J. Soil Sci. 62:187-195.

Blevins, D.W., D.H. Wilkison, B.P. Kelly, and S.R. Silva. 1996. Movement of nitrate fertilizer to glacial till and runoff from a claypan soil. J. Environ. Qual. 25:584-593.

Chichester, F.W., and C.W. Richardson. 1992. Sediment and nutrient loss from clay soils as affected by tillage. J. Environ. Qual. 21:587590.

Daigger, L.A., D.H. Sander, and G.A. Peterson. 1976. Nitrogen content of winter wheat during growth and maturation. Agron. J. 68: 815-818.

DeDatta, S.K., R.J. Buresh, M.I. Samsom, W.N. Obcemea, and J.G. Real. 1991. Direct measurement of ammonia and denitrification fluxes from urea applied to rice. Soil Sci. Soc. Am. J. 55:543-548.

Drury, C.F., C.S. Tan, J.D. Gaynor, T.O. Oloya, and T.W. Welacky. 1996. Influence of controlled drainage-subirrigation on surface and tile drainage nitrate loss. J. Environ. Qual. 25:317-324.

[FAO] Food and Agriculture Organization of the United Nations. 1995. World agriculture: Towards 2010. An FAO study. FAO and John Wily \& Sons, West Sussex, England.

[FAO] Food and Agriculture Organization of the United Nations. 2001. FAOSTAT [Online]. Available at http://apps.fao.org (verified 26 Mar. 2002).
Fowler, D.B., and J. Brydon. 1989. No-till winter wheat production on the Canadian prairies: Placement of urea and ammonium nitrate fertilizers. Agron. J. 81:518-524.

Francis, D.D., J.S. Schepers, and M.F. Vigil. 1993. Post-anthesis nitrogen loss from corn. Agron. J. 85:659-663.

Hardy, R.W.F., and U.D. Havelka. 1975. Nitrogen fixation research: A key to world food? Science 188:633-643.

Hargrove, W.L., D.E. Kissel, and L.B. Fenn. 1977. Field measurements of ammonia volatilization from surface applications of ammonium salts to a calcareous soil. Agron. J. 69:473-476.

Harper, L.A., R.R. Sharpe, G.W. Langdale, and J.E. Giddens. 1987. Nitrogen cycling in a wheat crop: Soil, plant, and aerial nitrogen transport. Agron. J. 79:965-973.

Hilton, B.R., P.E. Fixen, and H.J. Woodward. 1994. Effects of tillage, nitrogen placement, and wheel compaction on denitrification rates in the corn cycle of a corn-oats rotation. J. Plant Nutr. 17:13411357.

Johnson, G.V., and W.R. Raun. 1995. Nitrate leaching in continuous winter wheat: Use of a soil-plant buffering concept to account for fertilizer nitrogen. J. Prod. Agric. 8:486-491.

Large, E.C. 1954. Growth stages in cereals. Illustration of the Feekes Scale. Plant Pathol. 3:128-129.

Lukina, E.V., K.W. Freeman, K.J. Wynn, W.E. Thomason, R.W. Mullen, A.R. Klatt, G.V. Johnson, R.L. Elliott, M.L. Stone, J.B. Solie, and W.R. Raun. 2001. Nitrogen fertilization optimization algorithm based on in-season estimates of yield and plant nitrogen uptake. J. Plant Nutr. 24:885-898.

Mullen, R.W., W.E. Thomason, G.V. Johnson, K.W. Freeman, M.L. Stone, J.B. Solie, and W.R. Raun. 2001. Use of an in-season response index to predict potential yield increases from applied nitrogen. In 2001 annual meeting abstracts [CD-ROM]. ASA, CSSA, and SSSA, Madison, WI.

Raun, W.R., and G.V. Johnson. 1999. Improving nitrogen use efficiency for cereal production. Agron. J. 91:357-363.

Raun, W.R., G.V. Johnson, M.L. Stone, J.B. Solie, E.V. Lukina, W.E. Thomason, and J.S. Schepers. 2001. In-season prediction of potential grain yield in winter wheat using canopy reflectance. Agron. J. 93:131-138.

Raun, W.R., J.B. Solie, G.V. Johnson, M.L. Stone, R.W. Whitney, H.L. Lees, H. Sembiring, and S.B. Phillips. 1998. Micro-variability in soil test, plant nutrient, and yield parameters in bermudagrass. Soil Sci. Soc. Am. J. 62:683-690.

Rickman, R.W., S.E. Waldman, and B. Klepper. 1996. MODWht3: A development-driven wheat growth simulation. Agron. J. 88:176185.

Schepers, J.S., D.D. Francis, and M.T. Thompson. 1989. Simultaneous determination of total $\mathrm{C}$, total $\mathrm{N}$, and ${ }^{15} \mathrm{~N}$ on soil and plant material. Commun. Soil Sci. Plant Anal. 20:949-959.

Sembiring, H., H.L. Lees, W.R. Raun, G.V. Johnson, J.B. Solie, M.L. Stone, M.J. DeLeon, E.V. Lukina, D.A. Cossey, J.M. LaRuffa, C.W. Woolfolk, S.B. Phillips, and W.E. Thomason. 2000. Effect of growth stage and variety on spectral radiance in winter wheat. J. Plant Nutr. 23:141-149.

Solie, J.B., W.R. Raun, and M.L. Stone. 1999. Submeter spatial variability of selected soil and bermudagrass production variables. Soil Sci. Soc. Am. J. 63:1724-1733.

Stone, M.L., J.B. Solie, W.R. Raun, R.W. Whitney, S.L. Taylor, and J.D. Ringer. 1996. Use of spectral radiance for correcting in-season fertilizer nitrogen deficiencies in winter wheat. Trans. ASAE 39: $1623-1631$. 